Rui M. A. Machado - Maria do Rosàrio G. Oliveira

\title{
Tomato root distribution, yield and fruit quality under different subsurface drip irrigation regimes and depths
}

Received: 3 November 2004/ Accepted: 9 May 2005/ Published online: 2 August 2005

(C) Springer-Verlag 2005

\begin{abstract}
Tomato rooting patterns, yield and fruit quality were evaluated in a field trial where three irrigation regimes [0.6 (DI), $0.9(\mathrm{DII})$ and $\left.1.2 \mathrm{ET}_{\mathrm{c}}(\mathrm{DIII})\right]$ and three drip irrigation depths [surface (R0), subsurface at $20 \mathrm{~cm}$ depth (RI) and subsurface at $40 \mathrm{~cm}$ depth (RII)] were imposed following a split-plot experimental design, with four replications. The behaviour of the root system in response to the irrigation treatments was evaluated using minirhizotrons installed between two plants, near the plant row. Rootlength intensity $\left(L_{\mathrm{a}}\right)$ - length of the root per unit of minirhizotron surface area $\left(\mathrm{cm} \mathrm{cm}^{-2}\right)$-was measured at four crop stages. For all sampling dates, none of the factors studied were found to influence $L_{\mathrm{a}}$ or rooting depth significantly or the interaction between treatments. For all treatments most of the root system was concentrated in the top $40 \mathrm{~cm}$ of the soil profile, where the root-length density ranged from $0.5 \mathrm{~cm} \mathrm{~cm}^{-3}$ to $1.4 \mathrm{~cm} \mathrm{~cm}^{-3}$. The response of tomato fruits to an increase in the water applied was similar in quantitative and qualitative terms for the different drip irrigation depths. Water applied by drip irrigation had the opposite effect on commercial yield $\left(\mathrm{t} \mathrm{ha}^{-1}\right)$ and soluble solids ( ${ }^{\circ}$ Brix $)(r=-0.82, P<0.001)$, however, yield in terms of total soluble solids $\left(\mathrm{t} \mathrm{ha}^{-1}\right)$ was the same for the 0.9 and $1.2 \mathrm{ET}_{\mathrm{c}}$. The increase in commercial yield can be described by the equation (commercial yield $=-91.106\left(\% \mathrm{ET}_{\mathrm{c}}^{2}\right)+264.34\left(\% \mathrm{ET}_{\mathrm{c}}\right)-55.973, R^{2}=0,63$, $P<0.001)$.
\end{abstract}

Communicated by A. Kassam

R. M. A. Machado $(\bowtie) \cdot M$. do R. G. Oliveira

Instituto de Ciências Agrárias Mediterrânicas,

Universidade de Évora,

Apartado 94, 7002-554,

Évora, Portugal

E-mail: rmam@uevora.pt

Fax: + 351-266-760823

\section{Introduction}

Several investigations performed with different horticultural crops to analyse the influence of subsurface drip irrigation on crop yield show that when crops are fed by subsurface drips yields are equal to or greater than those obtained when fed by surface drips (Sammis 1980; Hutmacher et al. 1985; Phene et al. 1987; Bar-Yosef et al. 1991; Camp et al. 1993; El-Gindy and El-Araby 1996; Davis et al. 1997; Ayars et al. 1999; Machado et al. 2003). This behaviour can be attributed to factors affecting evaporation from topsoil (Camp 1998), such as the burying of the irrigation pipe with subsurface drip irrigation, which according to Phene (1991) and Phene et al. (1992) conduces the reduction of topsoil evaporation. However, several other factors have an influence on evaporation from topsoil: the water content of the soil surface resulting either from rainfall or irrigation, the degree of canopy development during the season and the influence of rainfall and irrigation on root growth and activity (Camp 1998). In processing tomato, during the first stages of crop growth, when the canopy is reduced, subsurface drip irrigation can increase the efficiency of water use when compared with surface irrigation (Machado 2002), due to a decrease in crop evapotranspiration $\left(\mathrm{ET}_{\mathrm{c}}\right)$. However, during the first stages of crop development the yield response factor $(k y)$ is low (Doorenbos and Kassam 1986). Similar yields using surface and subsurface drip irrigation could indicate that evaporation is the same from the moment the canopy effect begins to be felt. As the relationship between water consumption and production shows a sigmoidal curve, the hypothesis that there is a different response to the water supplied can be proposed for intervals where the curve slope is higher. The aim of the present study is then to determine the effect of different water regimes supplied by drip irrigation at different depths on tomato root development, distribution, yield and quality. 